\title{
Correction to: Comparative genomics and physiological investigation supported safety, cold adaptation, efficient hydrolytic and plant growth-promoting potential of psychrotrophic Glutamicibacter arilaitensis LJH19, isolated from night-soil compost
}

Shruti Sinai Borker ${ }^{1,2}$, Aman Thakur ${ }^{1,2}$, Sanjeet Kumar ${ }^{1}$, Sareeka Kumari ${ }^{1}$, Rakshak Kumar ${ }^{1 *}$ and Sanjay Kumar ${ }^{1}$

Correction to: BMC Genomics 22, 307 (2021)

https://doi.org/10.1186/s12864-021-07632-z

Following publication of the original article [1], it was reported that there was an error in Fig. 4. The originally published Fig. 4 was missing the following five enzymes: Argininosuccinate lyase $(\operatorname{argH})$, Arginine decarboxylase (speC), Agmatinase (speB), Polyamine aminopropyl transferase (speE), Ornithine decarboxylase (speC).

The correct figure is included in this Correction article and the original article has been updated.

\footnotetext{
Author details

'Biotechnology Division, CSIR-Institute of Himalayan Bioresource Technology Palampur, Palampur, Himachal Pradesh 176061, India. ${ }^{2}$ Academy of Scientific and Innovative Research (AcSIR), CSIR- Human Resource Development Centre, Ghaziabad, Uttar Pradesh 201 002, India.
}

Published online: 18 May 2021

\section{Reference}

1. Borker SS, Thakur A, Kumar S, Kumari S, Kumar R, Kumar S. Comparative

genomics and physiological investigation supported safety, cold adaptation, efficient hydrolytic and plant growth-promoting potential of psychrotrophic Glutamicibacter arilaitensis LJH19, isolated from night-soil compost. BMC Genomics. 2021;22(1):307. https://doi.org/10.1186/s12864-021-07632-z.

The original article can be found online at https://doi.org/10.1186/s12864 021-07632-z

*Correspondence: rakshak@ihbt.res.in; rakshakacharya@gmail.com

${ }^{1}$ Biotechnology Division, CSIR-Institute of Himalayan Bioresource Technology Palampur, Palampur, Himachal Pradesh 176061, India

Full list of author information is available at the end of the article

(c) The Author(s). 2021 Open Access This article is licensed under a Creative Commons Attribution 4.0 International License, which permits use, sharing, adaptation, distribution and reproduction in any medium or format, as long as you give appropriate credit to the original author(s) and the source, provide a link to the Creative Commons licence, and indicate if changes were made. The images or other third party material in this article are included in the article's Creative Commons licence, unless indicated otherwise in a credit line to the material. If material is not included in the article's Creative Commons licence and your intended use is not permitted by statutory regulation or exceeds the permitted use, you will need to obtain permission directly from the copyright holder. To view a copy of this licence, visit http://creativecommons.org/licenses/by/4.0/ The Creative Commons Public Domain Dedication waiver (http://creativecommons.org/publicdomain/zero/1.0/) applies to the data made available in this article, unless otherwise stated in a credit line to the data. 


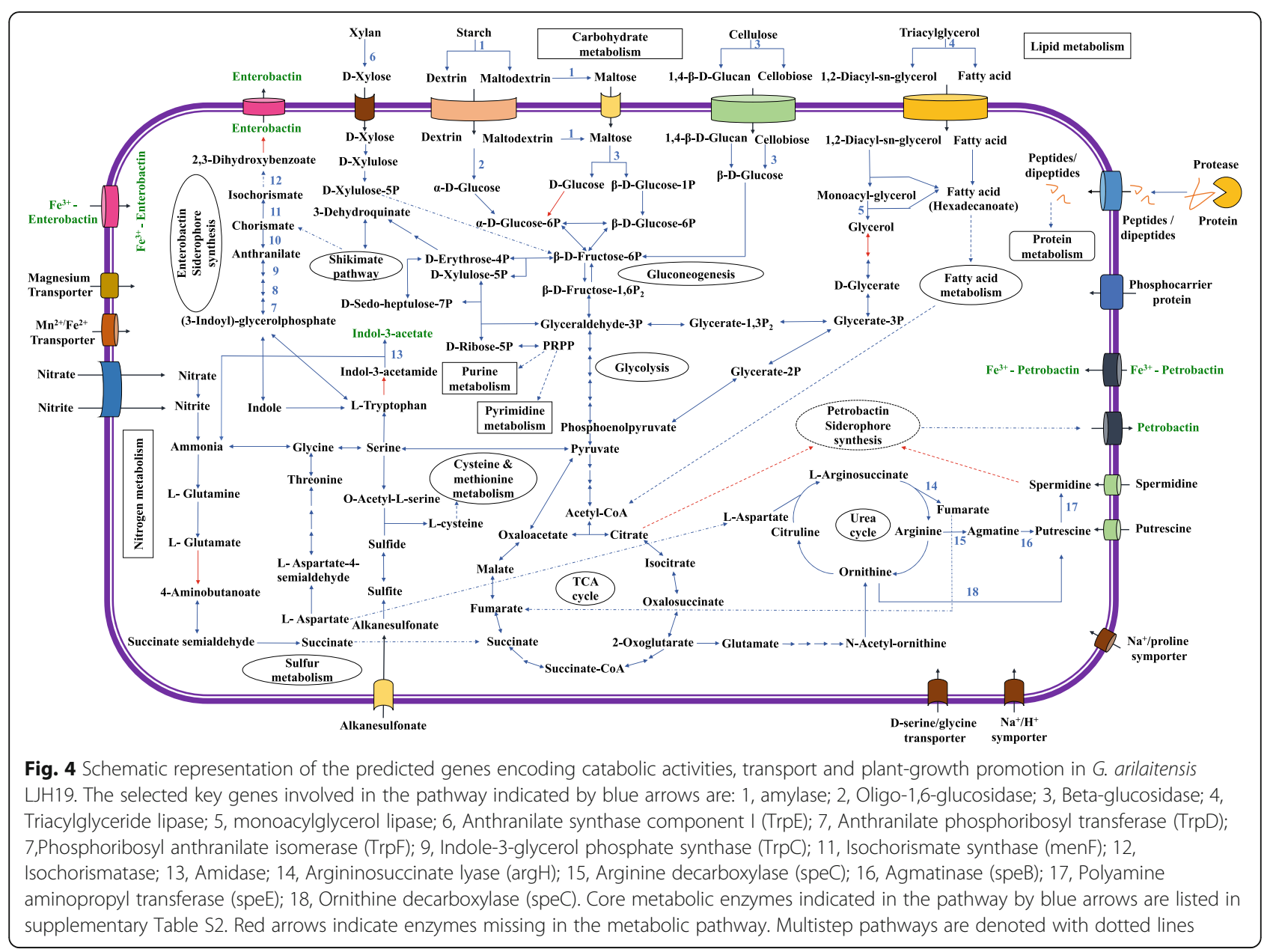

